\title{
Is the Brazilian fauna well represented on children's books?
}

\section{A fauna brasileira é bem representada em livros infantis?}

\author{
${ }^{1}$ Graziele Scalfi graziscalfi@gmail.com \\ 1 Germana Barata
}

\begin{abstract}
This paper examine children books about Brazilian fauna, especially those whose content reveals a potential for science communication. The research was conducted in Brazilian publishers, bookstores and in the Google search engine for books, using the keywords "animals", "Brazilian animals" and "national fauna". The content and descriptive analysis was performed in 24 books that presented wild animals in their natural habitat and portrayed realistically to verify the strategies used in the dissemination of animal biology, focusing on language, content and images. There is a significant number of books about Brazilian animals for children (199), but few are available for purchase (61). Only seven were considered adequate to disseminate animal science, indicating that few books associate scientific knowledge with quality text, bringing together information and aesthetics of the word, as well as beautiful and attractive illustrations. However, all titles play an important role in the popularization of native species.
\end{abstract}

Keywords: Brazilian fauna. Children’s literature. Science communication. Scientific culture.

\section{RESUMO}

Este artigo analisa os livros infantis sobre a fauna brasileira, especialmente aqueles cujos conteúdos revelam um potencial de comunicação científica. A pesquisa foi realizada em editoras brasileiras, livrarias e na ferramenta de busca Google, usando as palavras-chave "animais”, “animais brasileiros” e "fauna nacional”. A análise de conteúdo e descritiva foi realizada em 24 livros que apresentaram animais silvestres em habitat natural e que não eram humanizados para verificar as estratégias usadas na divulgação da biologia animal, com foco na linguagem, conteúdo e imagens. Há um número significativo de livros sobre animais brasileiros para crianças (199), mas poucos estão disponíveis para compra (61). Apenas sete foram considerados adequados para divulgar a ciência animal, indicando que poucos livros associam o saber científico a textos de qualidade, reunindo informação e estética da palavra, bem como de ilustrações bonitas e atraentes. No entanto, todos os títulos desempenham um papel importante na popularização de espécies nativas.

Palavras-chave: Fauna brasileira. Literatura infantil. Comunicação científica. Cultura científica.

\footnotetext{
1 Universidade de São Paulo (USP)
} 


\section{INTRODUCTION}

Out of the 8.7 million estimated animal species on Earth, 6.5 million are terrestrial species and 2.5 million are marine species (MORA et al., 2011). However, despite efforts in taxonomic classification, the number of animal species described and cataloged to date is approximately 1.5 million (CBD, 2015). Due to its territorial extension, climatic and geographic diversity, Brazil shelters 15 to $20 \%$ of the described animal species, the largest number of endemic species in the world (CBD, 2015; LEWINSOHN; PRADO, 2005) and two of the 19 global hotspots: the Atlantic Forest and the Cerrado.

More than 206 million Brazilians (IBGE, 2016) coexist with this extraordinary biodiversity, which, in turn, makes the country face the great challenge of managing the integration between society and the environment, making people aware of environmental problems and motivating them to participate in their solutions by promoting sustainable development, conservation of fauna and flora and a sense of personal responsibility regarding their attitudes towards the environment.

A survey on public perception of biodiversity (UEBT, 2015) held in 16 countries from 2009 to 2015 revealed that there is a long way to go before achieving the United Nations 2020 target for citizens' awareness of biodiversity and its importance. Only half of more than 16,000 respondents were able to define "biodiversity", and Brazil was among the nations with the best understanding of the concept - over $90 \%$. Biodiversity, however, is still the word with the lowest awareness (69\%), compared to deforestation (93\%), sustainable development (84\%) and global warming (97\%).

Corroborating this results, a study by Evans et al. (2007) shows that in countries where children and adults have less contact with nature, the level of awareness about local environmental issues and the ecosystems is lower, and people are remarkably apathetic regarding the environment.

In Brazil, due to the length of its territory and the concentration of population in urban areas, distant from biomes and the native fauna and flora, few people have the opportunity to visit forests and natural reserves that provide contact with the wildlife. As a result, this may be a factor that contributes to the Brazilian's low level of knowledge about the local fauna and flora, as demonstrated by ample research (BALLOUARD; BRISCHOUX; BONNET, 2014; BIZERRIL, 1999; SCALFI et al., 2004; SCHWARZ et al., 2007).

The low level of knowledge about the national fauna may be partially explained by the focus on exotic animals - especially large African mammals - in the media, in movies, cartoons, games, children's books and documentaries. Therefore, three-year-old children will frequently be able to identify exotic animals such as the lion, the hippo, the giraffe and the elephant; or others, such as the kangaroo, the gorilla and the panda bear; but won't be able to recognize Brazilian animals such as the tapir, the maned wolf, the manatee or the anteater. Aside from the fact that large mammals fascinate children, especially the African ones because of their great size, also contributes to this discrepancy the incipient work of science communication about animals from the Brazilian fauna, which have to compete against the immense popularity of foreign cartoons, films and children's books.

The influence exerted by the media on children's and adolescents' perception of animals is so important that some research shows that fictional characters can be more easily recalled and named than real animals (BALMFORD, et al 2002; HENLEY, 2010). On the one hand the digital age has provided children with access to information about the natural world with one click, broadening the knowledge and the curiosity about species; on the other, it increases sedentary activities related to the use of electronic media, decreasing real and direct contact with nature (PERGAMS; ZARADIC, 2006).

In Brazil, for instance, the average time a child spends in front of the television is increasing. Data from the National Television Panel, conducted in 2014 by Ibope Media, shows that children between ages 4 and 17 are exposed to TV for 5h 35min per day - 52 minutes more than in 2004, and above the national average time, 
which is 4h 31min (BRASIL, 2015). Ibope's survey also shows that Brazilian children are also connected to the internet longer, and those between ages 2 and 11 are online for about 17 hours per month ${ }^{2}$. Despite the time they spend in front of the screens (TV, tablets, cell phones or computers), there are still few programs, cartoons or films that portray the Brazilian fauna. Among them, two initiatives stand out: the film Rio (directed by Carlos Saldanha, 2011) and the cartoon Fishtronaut3 (created by Celia Catunda, 2009), both of which were shown in movie theaters in Brazil.

These data reinforce the need for countries to promote learning about the environment starting from childhood, so that children can build a sense of admiration and respect for native biodiversity and grow up with an awareness of such diversity and the need to preserve it. Thus, we believed that it is at this stage that there should be greater incentives to start learning about animals, providing appropriate explanations for each age group and as much information as necessary. Morgan and Gramann (1989) add that presenting wildlife in childhood contributes not only to learning but also to positive changes in attitudes, awareness, and actions towards wildlife.

In this context, books are a source through which children are likely to receive information on wildlife (HUXHAM, 2010) and are one possible way to help with the popularization, dissemination and enhancement of knowledge related to native species, since contact and experience with wild animals are not always possible.

The survey Portraits of Reading in Brazil conducted by Pro-Livro Institute (2012) ${ }^{4}$ concludes that the habit of reading is developed from childhood and is strongly influenced by adults, especially the mother. The research also points out that the higher the education level and income, the more books a person reads, especially those required by school, whether they are textbooks or literature. This is of great importance, since it demonstrates the relevance of offering good books at younger and younger ages, both to cultivate the habit of reading and the taste for acquiring knowledge.

Compared to other countries, Brazil is still struggling to develop the population's reading habits. Although the average of books read per person in a year has increased from 1.8 copies in 2011 to more than 4 copies in 2015 (PORTRAITS OF READING IN BRAZIL, 2015), a study carried out by the United Nations Organization for Education, Science and Culture [Unesco] shows that in a reading rank of 52 countries, Brazil is on the $47^{\text {th }}$ position. In developed countries, a person reads on average 10 books a year.

According to the National Association of Bookstores [ANL] (2012), the low reading average in Brazil can be explained by the low number of bookstores and the lack of national distribution ${ }^{5}$, which in turn results in fewer points of sale and fewer titles launched every month, resulting in increasingly smaller print runs - with the exception of a few bestsellers - and hence higher prices, which reduces the number of readers. Therefore, encouraging editorial policies and publications aimed at children can contribute to develop the taste for reading.

Introducing children to reading in the pre-literacy period is an important strategy for training new readers. Because they are at a crucial stage to explore their curiosity, to expand their vocabulary and are can easily feel enchanted by topics that may be relevant to citizenship and scientific culture. As a result, reading varied texts, such as literature, comics, poetry and fiction, can be an effective strategy to stimulate childrens' interest, to expand knowledge and to motivate learning of topics related to science (Ribeiro; Kawamura, 2011), including the science of the animal world.

2 For the $48 \%$ of Brazilians who say they use the internet, the average daily connection time is 4h 59 min. (BRAZIL, 2015).

3 Fishtronaut is a Brazilian cartoon created by Celia Catunda Kiko Mistrorigo that presents Brazilian animals while dealing with ecology and sustainability. It was produced by TVPinGuim and broadcast by the Discovery Kids channel and TV Cultura network.

4 The survey included 5,012 people in 315 municipalities in 2011.

5 According to the ANL (2012) Brazil has 3,073 bookstores in 5.7 million municipalities. UNESCO recommends a ratio of 10.000 inhabitants per bookstore. With a population of 204 million inhabitants, the country's ratio is much lower than expected, with at least one bookstore in $27.4 \%$ of Brazilian municipalities (IBGE, 2016). 
Therefore, books that aim to popularize science offer possibilities to learn and have fun, have been shown to be an effective tool to help introduce and present the genuinely Brazilian species and to make children aware of the importance of preserving them. But is the Brazilian fauna well represented in children's books?

Our hypothesis in this paper is that the Brazilian fauna rarely appear in children's literature, which focuses on exotic animals - especially large mammals, and, above all, African ones - and domestic animals. Our main objective is to examine national and foreign children's books available in the Brazilian market with the potential to popularize Brazilian fauna and to evaluate how the authors approach the topic in the text and images.

\section{METHODOLOGY}

The survey of children's books about Brazilian fauna was conducted from March 2012 to December 2013, in 4 publishers ${ }^{6}$ and the Google search tool, using the keywords “children's books” and “animals”, "Brazilian animals" or "Brazilian fauna” in Portuguese. We excluded books intended for babies, with titles in English, on domestic animals, as well as short stories or books that presented animals as characters in the synopsis, but which addressed other subjects, as learning numbers, colors or shapes. In this first phase we obtained 199 titles $^{7}$ with potentially dealt with the Brazilian fauna.

From this first sample, we excluded books that were unavailable ${ }^{8}$ for purchase from November to December 2012 or exceeded more than two titles by the same author for each collection. We have obtained 61 books for content analysis, which we called the research sample9.

The titles were classified according to author, year of publication, publisher, edition, place of publication and origin of the work, whether they were Brazilian or foreign titles, and sorted according to the way animals were portrayed, whether realistically (as wild animals and animals in their natural habitat) or in an anthropomorphic way (i.e., fictional characters). For content analysis (Bardin, 2011) we selected the books for children between ages 3 and 7 - according to the description in the book -, which presented wild animals in their natural habitats and with realistic features ${ }^{10}$.

We obtained a total of 24 titles (Appendix A) that underwent descriptive analysis, taking into account different categories, such as: narrative style, font, content, conceptual terms, possibilities of interaction; and the way animals are represented in the text, so that we could evaluate the content, the form and the language, and the literary consistency, aiming to select books that focus on science communication and are capable of describing the animal and its biology, its ecology, etc., in an attractive, engaging and instructive way.

6 An email was sent to 28 publishers in the country, and only four of them answered with the requested information: Brinque-Book, Callis, Cosac Naify and Peirópolis. Therefore, it was also necessary to visits some physical bookstores: Cultura and Livraria da Vila, and check two major online stores: Saraiva, Submarino, as well as the Google search engine to make sure a greater number and variety of books was obtained.

7 Table 1 - Books obtained in the survey. Available in: http://migre.me/w4KHL

8 These books were unavailable in November / December 2012, when we bought the books for the research at Livraria Cultura, or they were not available at the supplier.

9 Table 2 - Characterization and morphology of the sample. Available in: http://migre.me/w4KJR

10 In these books, animals are portrayed according to their natural characteristics, they look like real animals and they don't have human features. 
Figure 1 - Representation of the universe of books related to the research.

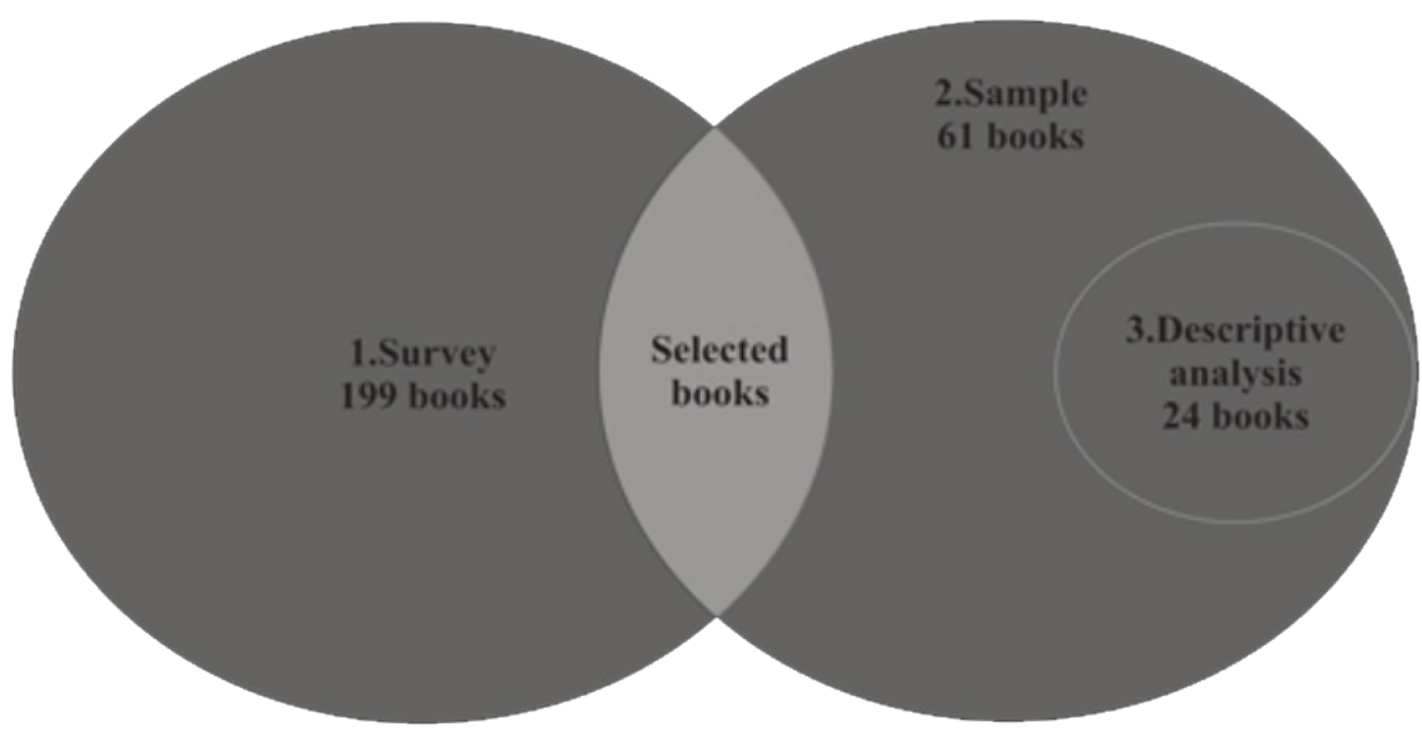

1. Books about animals which potentially include the Brazilian fauna

2. Books available for purchase, with a reduced number of titles per author/collection and preferably about Brazilian animal,

3. Books targeting ages 3 to 7, with wild animals in their natural habitat and portrayed realistically.

Source: Author's elaboration.

\section{RESULTS}

Contrary to the initial hypothesis that Brazilian animals are rarely included in children's literature, we found an expressive number of books on the subject. From a total of 199 books, 69\% of them referred to Brazilian animals in the synopsis, cover or title, and there was a significant number of collections and series of books on this topic. Considering the 96 authors identified, 27 had written a collection of books on animals in general.

Despite the number of books found, many titles were not available for purchase. When checking the availability of the 199 titles, we noticed that $30 \%$ of them were unavailable or sold out during the period of the survey. Also, among the 61 books purchased for research, $49 \%$ had to be ordered, $5 \%$ were found in used bookstores and $2 \%$ were available for free download. We therefore considered the availability of children's books about Brazilian animals low. Among the 61 selected titles, which formed the research sample of this analysis, 44 (72\%) were national publications and the remaining titles were translations. We included translated books in our research sample because we wanted to check if they included animals of the Brazilian fauna and, if so, how they were portrayed. The translated titles were generic and did not address any specific wild Brazilian animal. Essa não é minha cauda (This is not my tail), by Carla Baredes and Illeana Lotersztain (Editora Callis, 2006) and Animais incríveis (Incredible animals), by Martin Cam (Editora Girassol, 2011) are some examples (Figure 2). The covers and the images in the books follow the same pattern, as they do not depict wild animals from the Brazilian fauna, only a variety of other animals.

The national titles examined, however, deal with Brazilian fauna more often. In some books the title presents the animals by their popular name: Quem já viu um bugio?, (Have you ever seen a bugio monkey?), by Denise Patrício (Editora Edifurb, 1999); O lobo-guará (The maned wolf), by Rubens Matuck (Editora Biruta, 2006), A onça e a anta (the jaguar and the tapir), by Sonia Junqueira (Editora Atica, 2007), A onça pintada (The Panthera onca), by Alba Capelli and Dora Dias (Editora FTD, 2008) and A arara e o guaraná (The macaw and 
the guarana), by Ana Maria Machado (Editora Ática, 2012). In other books, the titles referred to the Brazilian national identity, such as Brasileirinhos (Little Brazilians), by Lalau (Editora Cosac Nayf, 2001), Bichos do Brasil (Brazilian animals), by Gabriela Brioschi (Editora Odysseus, 2004), Boniteza Silvestre (Wild beauty), by Lalau (Editora Peirópolis, 2007), Animais da nossa terra (Animals from our land), by Marcia Riederer (Editora Cuca Fresca, 2008), História de bichos brasileiros (History of Brazilian animals), by Val Do Vera (Editora Martins Fontes, 2010), among others. When titles are general, as in O livro do pé (The book about the foot) - Angelo Machado (Editora Le, 2012), Bicharada em perigo (Animals in danger), by Fabio Terni (Editora Girafinha, 2007), Belezura marinha (Marine beauty), by Lalau (Editora Peirópolis, 2010), the books still focus on Brazilian animals in their illustrations (Figure 2).

\section{Figure 2 - A and B - Foreign books; C and D - Brazilian books.}

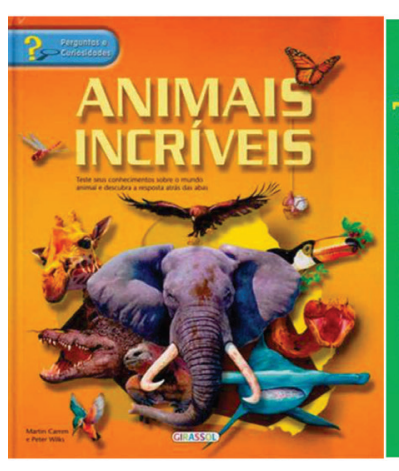

A

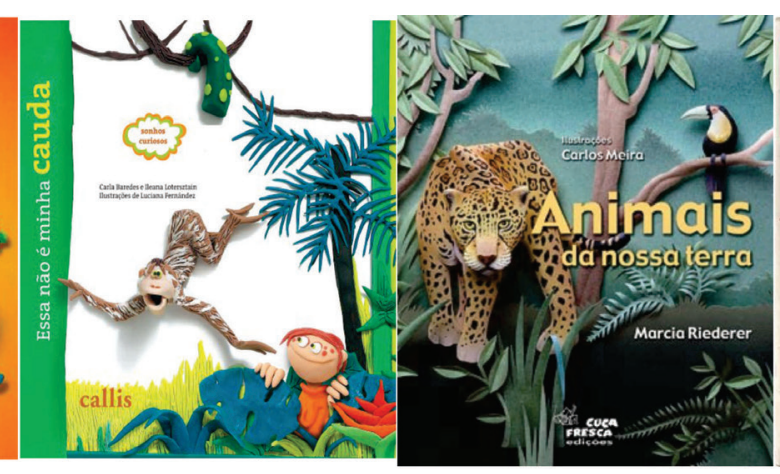

C

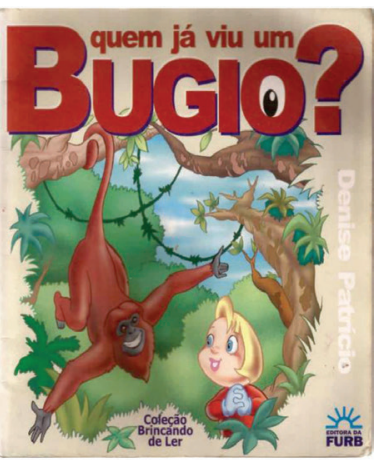

D

Sources: Reproduction by Editora Girassol, Editora Callis, Editora Cuca Fresca and Editora Edifurb respectively.

All the books examined with interactive resources (12) were translated. We believe that this absence of Brazilian interactive books is mainly due to the high production costs in the country. For this reason, most interactive books produced in Brazil are printed in China and Thailand, where costs are low, using a co-printing or co-editing system - in which the publisher that owns the copyright of the book collaborates with publishers from several countries and arranges the printing of the copies in Asia.

The analysis of the 61 titles of the research sample also showed that only 2 titles presented anthropomorphized animals from the beginning to the end of the book, namely: $O$ veado e a onça (The deer and the jaguar), by Ana Maria Machado (Editora FTD, 2004), and O tamanduá chorão (The crybaby anteater), by Mirna Pinsky (IBEP Publishing, 2011). Most of the books (43) represent animals according to their natural (animal) features and natural environment - these books, therefore, are more adequate for science communication. The other 16 titles combine both animal and human features in the images, indicating a blend of reality and fiction that is common in children's stories.

\section{1 Descriptive analysis}

Our descriptive analysis of the 24 books showed that books that popularize the Brazilian fauna have a variety of literary styles, with a predominance of prose (18). However, 6 books were narrated in verses, which we considered a surprisingly high number, since, according to previous studies (AMARRILHA, 1997; RAMOS; TORQUINST, 2012), this narrative style finds little space in the market.

Our analysis also found that the books about the Brazilian fauna highlight the animals on the cover and/or title; and the most popular Brazilian animal in children's books, whether on the cover, main text or illustrations is the jaguar (Panthera onca), followed by the maned wolf (Chrysocyon brachyurus) and the anteater (Myrmecophaga tridactyla), three mammal species threatened with extinction. 
It also showed that books about the national fauna for 3 and 4 year-old children are a minority, and the few ones we found focus on learning how to read, exploring topics such as the alphabet, words and phrases. In other words, there is little concern in presenting animals of the Brazilian fauna and their characteristics. Books for children between ages 5 to 8 were the most frequent in the examined books, with a total of 23 titles.

In relation to the font used, the print letters, press style (upper and lowercase) and capital letters (uppercase) are the most common in the books. The selected books and the ones that underwent descriptive analysis don't use cursive letter (handwriting) in their texts. Among the books that use print letters, we observed that the books for learning how to read used uppercase letters. When the books has a different objective (arousing the pleasure of reading, entertaining, providing information, among others), the preference is given to the press style font, using both the upper and the lower case, which may not favor the autonomy of children who are starting to read.

Only one book contained mistakes: Bichos de lá e cá (Animals from there and there), by Lia Neiva (Editora Ediouro, 2004). In the book, the kinship between the jaguar and the lion is questioned in two sentences, one that asserts that the jaguar is the lion's cousin and the other where this assertion is contested, conveying the impression, that they are not relatives. Both animals, however, belong to the Felidae family of felines, which could have provided an important opportunity for science communication.

In order to classify how animals are portrayed in the stories, we used Arbuthnot's three-category classification (1957): (1) "Humans in animal skin", with anthropomorphic animals who speak to other animals and have the attitudes, weaknesses and virtues of human beings. These animals bear little or no similarities to the biological species; (2) "Animals portrayed as animals but who talk as humans," with animals whose only human attributes are the capabilities of thought and expression. In other words, these texts present animals realistically, focusing more on their biological characteristics than anthropomorphic (human) characteristics. (3) "Animals as they are” with animals portrayed in a more realistic way, avoiding anthropomorphism, and behaving strictly as animals.

The representation of "humans in animal skin" was found in nine titles. In the book Um tronco no meio do caminho (A trunk in the middle of the way), by Rosana Rios (Editora Positivo, 2010), for example, portrays the jaguar, in images and text, as a strong animal: "Have you noticed how strong I am? The jaguar meowed - I've saved everyone.” The book explores human virtues, proposes a reflection on the relations between the strongest and the weakest as well as on prejudices.

According to More (1977), children's preferences regarding the theme of animals in literature vary according to the age and content of the story. Stories in which animals are humanized the children's favorite. This occurs, perhaps, because they can recognize characteristics of adults in the characters and, therefore, relate to the story. More (1977) recalls that as children grow older, the taste for books also changes. And then, they begin to prefer the stories of animals represented as animals, but that are still able to speak. In the descriptive analysis, five books presented this attribute: $A$ onça pintada (The jaguar), by Alba Capelli and Dora Dias (Editora FTD, 2008); A corrida de Mada (Mada's race), by Beatriz Ribeiro (Editora Roda e Cia, 2009); Lobo guará de hotel (Hotel maned wolf), by John Bosco Bezerra Bonfim (Editora Callis, 2009); The foot's book (The book of the foot), by Angelo Machado (Editora Le, 2012), and Tatu bobo (Silly armadillo), by Ana Maria Machado (Editora Salamandra, 2012). In these books, animals speak and in some cases they tell their own story. However, their biological characteristics, as species, are maintained, as in the following example:

During my journey, I learned how to warm myself up with the sand, how to run with my brothers, how to let myself go in the water and how not to fear my enemies ${ }^{11}$

What about the macaw's foot?

How different it is!

It has two fingers pointing backwards

and two fingers pointing forward ${ }^{12}$

11 Translation from the original in Portuguese on the book A corrida de Mada - Magda's race - by Beatriz Ribeiro

12 Translation from the original in Portuguese on the book O livro do pé - The foot book - by Angelo Machado 
For "animals as they are", the third type of animal representation in children stories, we found a total of 10 books, portraying animals objectively and with their natural features. Among them are: Peixe ou boi (Fish or ox), by Carmen Figueiredo (Author's edition, 2001); O lobo-guará (The maned wolf), by Rubens Matuck (Editora Biruta, 2006); and Lobo-guará (The maned wolf), by Cristina Luna (Editora ao Livro Técnico, 2006); Boniteza Silvestre (Wild beauty), by Lalau (Editora Peirópolis, 2007); and SOS lobo guará (SOS maned wolf), by Ciça Esch (Editora All Print, 2012).

When animals are portrayed with greater objectivity and realism, it is important to be careful about the level of the information offered. These books often strive to offer such conceptual accuracy that they seem to meant for experts, treating children as "small-biologists.” Books that present correct information and concepts coupled with light-hearted stories are the most successful ones in terms of science communication.

However, the descriptive analysis of this study indicates that there are only a few books about science for children with these characteristics. Although all titles play an important role in the science communication related to the Brazilian fauna, presenting animals that are not usually explored in children's books - few of these titles were actually designed to do so. In fact, according to the criteria established in the analysis, among the 24 titles analyzed, only 7 books (Figure 3) were considered as adequate to communicate science of the animal world, as being capable of awakening the reader's interest in the Brazilian fauna, and as having managed to unite literary form and scientific information in a pleasant way. They were: Brasileirinhos (Little Brazilians), by Lalau (Editora Cosac Nayf, 2001); Bem brasileirinhos (Proud Little Brazilians), by Lalau (Editora Cosac Nayf, 2004), The maned wolf (O lobo guará), by Rubens Matuck (Editora Biruta, 2006), Boniteza Silvestre (Wild beauty), by Lalau (Editora Peirópolis, 2007), Rimas da floresta (Rhymes from the forest), by José Santos (Editora Peirópolis, 2007), A corrida de Mada (Mada’s race), by Beatriz Ribeiro (Editora Roda e Cia, 2009) and O livro do pé (The foot book), by Angelo Machado (Editora Le, 2012).

Figure 3 - Books considered as effective in terms of communicating science of Brazilian fauna.

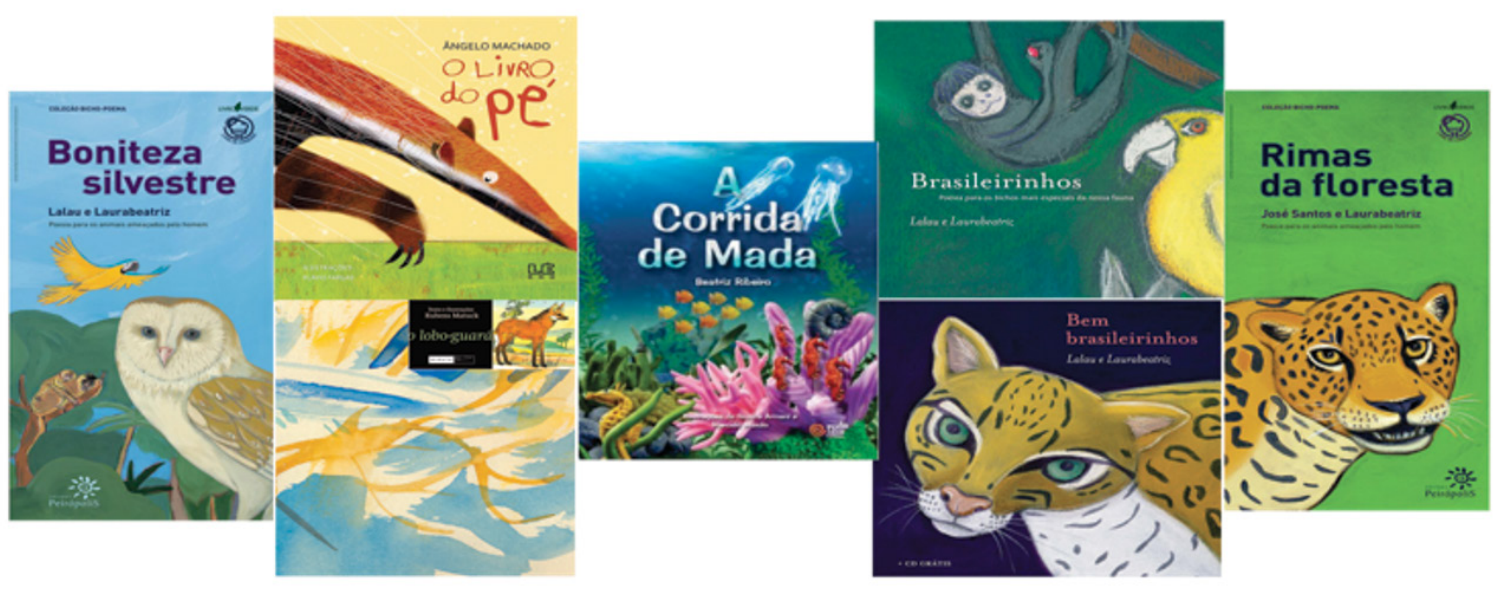

Sources: Reproduction by Editora Peirópolis, Editora Le, Editora Biruta, Editora Roda e Cia and Editora Cosac Nayf. 


\section{CONCLUSION}

There is a considerable number of children's books, in Brazil and worldwide, which can be excellent motivators for raising interest in Brazilian animals. However, when we examined the books available for purchase that deal specifically with Brazilian animals in the perspective of science popularization, we discovered that the number of books available on this topic is rather reduced.

Our analysis showed there are good examples in children's literature that highlight the Brazilian fauna and - regardless of the narrative style, purpose, illustrations, etc., - play an important role in the science popularization of Brazilian animals simply by presenting those animals. With the descriptive content analysis presented in this paper (24 books) we concluded that between the books that communicate the biology of the national fauna and literature books, we identified some that are effective for science communication of the Brazilian fauna. There are some good options of titles in the market that deal with Brazilian animals, habitat, fauna, feeding habits, among other curiosities, while they also tell a good story, entertain, are fun, and enchant. However, because those books are few, we consider that there is room for the production of more science communication books for children.

We believe it is necessary to invest more in books that associate scientific knowledge with quality text, bringing together information and literary style, as well as beautiful and attractive illustrations. With such books, it is possible to engage and inspire readers while also raising their awareness, stimulating the construction of new knowledge and promoting citizenship, as well as helping children understand the relevance of the Brazilian fauna and its conservation.

Another aspect revealed by the sample analysis is that some of the most attractive books are interactive, produced by a foreign author outside of Brazil and involving higher production costs. This leads us to two observations, one related to the high costs of printing in the country due to several structural economic factors, but also to the lack of incentives and strategies for the production of interactive books, even if it is produced in a foreign country.

A plausible conclusion is that there seems to be a greater concern with the production of science books for children in developed countries. The data obtained by our research corroborate this statement, since only 4 of the selected titles are considered as science communication books and they are all foreign: Senhor cavalo-marinho (Mister Sea horse), by Eric Carle - EUA; O maior, o mais perigoso e outros animais interessantes (The biggest, the most dangerous and other interesting animals), by Jozua Douglas - Holanda; Essa não é minha cauda (This is not my tail), by Carla Baredes e Illeana Lotersztain - Argentina; and Essas não são minhas patas (These are not my paws), by Carla Baredes e Illeana Lotersztain - Argentina).

Therefore, much can still be done in Brazil to boost this segment, either through the creation of incentive programs, or through awards as a form of recognition and incentive for projects with such an approach. It is important to expand initiatives that invest in public tenders and credit lines to produce books that popularize science of the Brazilian fauna to children, by agencies such as the National Council for Scientific and Technological Development (CNPq), the state foundations that support research, the Ministry of Education and Environment, the National Library, among others, as well as environmental NGOs. These are some of the possibilities to mobilize writers and scientists to produce more books in an effort to make the Brazilian fauna part of the vocabulary of Brazilian children and adults. 


\section{REFERENCES}

Amarillha, M. Estão mortas as fadas: literatura infantil e prática pedagógica. Petrópolis: Vozes, 1997.

Associação Nacional de Livrarias (2012). Diagnóstico ANL do setor livreiro 2012. Retrieved on November 3, 2012 from: http://anl.org.br/web/diagnostico.html

Arbuthnot, M. H. Children and books. Chicago: Scott Foresman and Company, 1957.

Ballouard, J-M.; Brischoux, F.; Bonnet, X. Children Prioritize Virtual Exotic Biodiversity over Local Biodiversity. PLoS ONE, v.6, n.8, p.1-8, 2011. doi: 10.1371/journal.pone.0023152

Balmford A., Clegg L., Coulson T., \& Taylor J. Why conservationists should heed Pokémon? Science, v.295, p.2367-2371, 2002. doi: 10.1126/science.295.5564.2367b

Bardin, L. Análise de conteúdo. São Paulo: Edições 70, 2011.

BIZERRIL, M. X. A. Children's Perceptions of Brazilian Cerrado Landscapes and Biodiversity. The Journal of Environmental Education, v.35, n.4, p.47-58, 1999. doi: 10.3200/JOEE.35.4.47-58

BRASIL. Presidência da República. Secretaria de Comunicação Social. Pesquisa brasileira de mídia 2015: hábitos de consumo de mídia pela população brasileira. Brasília: Secom. Retrieved on January 13, 2016 from: http://www.secom.gov.br/atuacao/pesquisa

CONVENTION ON BIOLOGICAL DIVERSITY (2016). Brazil - Country Profile: Biodiversity Facts. Retrieved on January 31, 2016 from: https://www.cbd.int/countries/profile/default.shtml?country=br\#facts

EVANS, S.; GARSIDE, C.; GEBBELS, S.; STOCKILL, J.; GRENN, M. The 'citizens' day: encouraging young people to acquire, value and use environmental knowledge. School Sci. Rev. v.88, n.325, p.45-50, 2007.

HENLEY, J. Why our children need to get outside and engage with nature, Retrieved on August 16, 2010 from: http://www.guardian.co.uk

HUXHAM, M.; WELSH, A.; BERRY, A.; TEMPLETON, S. Factors influencing primary school children's knowledge of wildlife, Journal of Biological Education, v.41, n.1, p.9-12, 2006. doi: 10.1080/00219266.2006.9656050

INSTITUTO BRASILEIRO DE GEOGRAFIA E ESTATÍSTICA. Perfil dos Municípios Brasileiros: 2015. Rio de Janeiro: IBGE, 2016.

INSTITUTO PRÓ-LIVRO. Retratos da Leitura no Brasil 3. São Paulo: Instituto Pró-livro e Imprensa Oficial do Estado de São Paulo, 2012.

LEWINSOHN, T.L.; PRADO, P.I. Quantas espécies há no Brasil? Megadiversidade v.1, n.1, p.36-42, 2005.

MORA, C.; TITTENSOR, D.P.; ADL, S.; SIMPSON, A.G.B.; WORM, B. How Many Species Are There on Earth and in the Ocean? PLoS Biol v.9, n.8, 2011. doi:10.1371/journal.pbio.1001127

MORGAN, J. M.; GRAMANN, J. H. Predicting effectiveness of wildlife education programs: A study of students’ attitudes and knowledge toward snakes. Wildlife Society Bulletin, v.17, n.4, p.501-509, 1989.

PERGAMS, O.; ZARADIC, P. Is love of nature in the US becoming love of electronic media? 16-year downtrend in national park visits explained by watching movies, playing video games, internet use, and oil prices. J Environ Manage, v.80, p.387-393, 2006. doi: 10.1016/j.jenvman.2006.02.001_ 
RAMOS, F. B.; TORQUINST, S. R. A. A construção do poético em Quando as montanhas conversam. Acta Scientiarum. Maringá, v.34, n.1, p.9-15, 2012.

RIBEIRO, R. A.; KAWAMURA, M. R. D. Divulgação científica para o público infantil: potencialidades da revista Ciência Hoje das Crianças In: XIX SIMPÓSIO NACIONAL DE ENSINO DE FÍSICA, 2011, Manaus. Anais... Manaus, Amazonas, Brasil.

SCALFI, G. A. M. Fauna brasileira retratada na literatura infantil: instrumento para divulgação científica, 2014, f... Dissertação (Mestrado em Divulgação Científica) Instituto de Estudos da Linguagem, Universidade Estadual de Campinas, São Paulo, Brasil.

SCHWARZ, M. L., SEVEGNANI, L.; ANDRÉ, P. Representations of the Atlantic Rain forest and its biodiversity through children's drawings, Ciência \& Educação, v.13, n.3, p.369-388, 2007. doi: 10.1590/ S1516-73132007000300007

UNION FOR ETHICAL BIO TRADE. UEBT Biodiversity Barometer 2009-2015. Retrieved on March 24, 2016 from: http://ethicalbiotrade.org/dl/UEBT\%20-\%20EN\%20Barometer\%202015.pdf 
APPENDIX A.

\section{BOOKS THAT COMPOSED THE DESCRIPTIVE ANALYSIS}

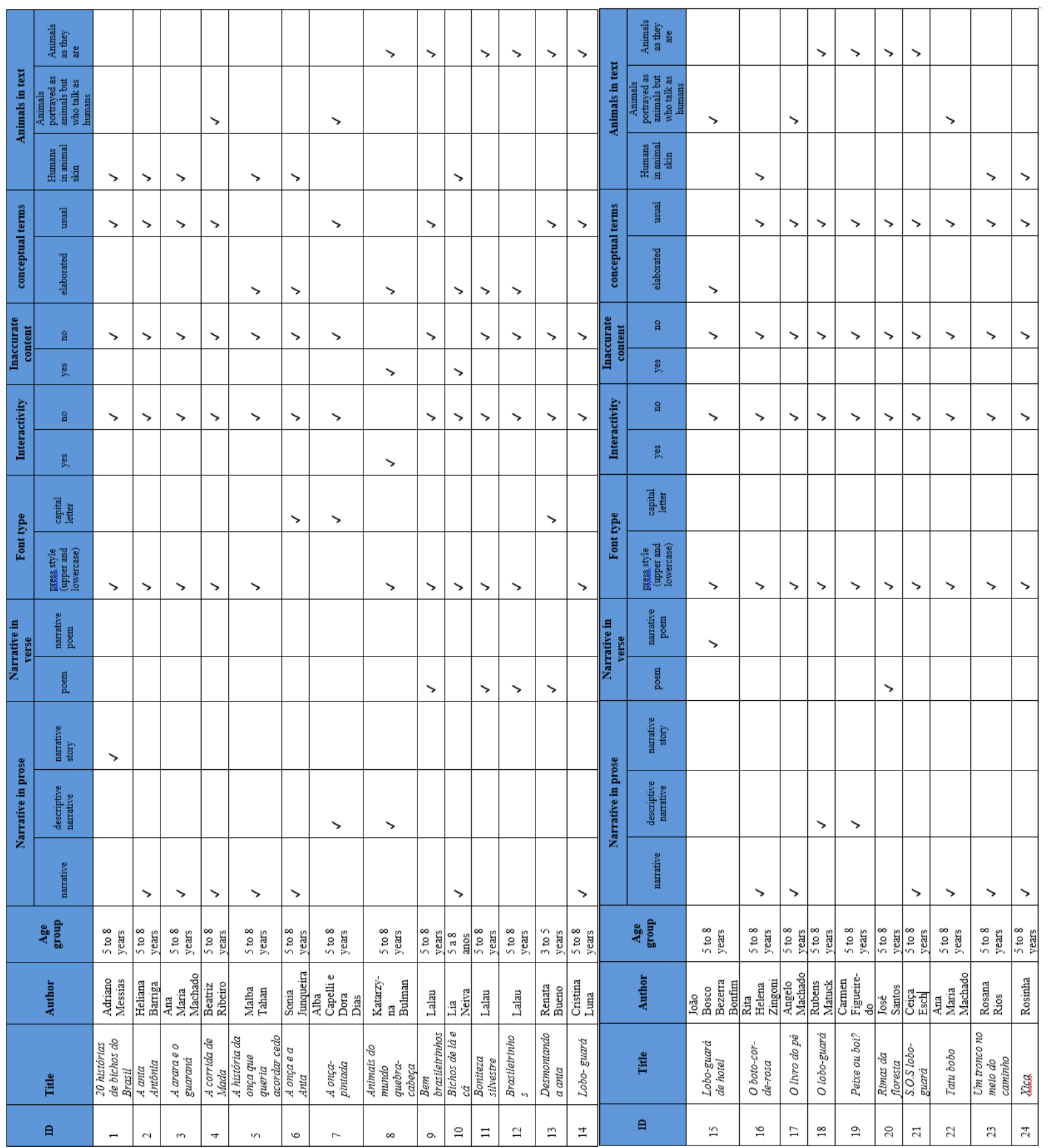

